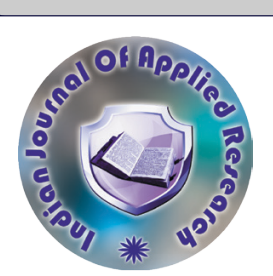

Philosophy

\title{
SPIRITUAL COUNSELLING AS A MODE OF INTERVENTION TO ALCOHOL ADDICTION
}

\section{Dr. D. Prince Annadurai \\ ABSTRACT}

Assistant Professor, Department of Social Work, Madras Christian College, Chennai600059

Alcohol addiction has become wide and extensive in today's world and it is one of the haunting task the country faces in the 21 st century. There are many treatment models of de-addiction implemented in various centers of de-addiction which includes group therapy, family therapy, and behavioral therapy. However, spiritual counselling approach is not given its importance though it significantly helps in de-addiction treatment. This study focuses on the effectiveness of spiritual counselling as a mode of intervention on persons addicted to alcohol. The study was conducted in TRADA- a Christian de-addiction center in Kottayam. The research aims to study thelevel of depression among alcoholics, attitude towards life and mental health, coping and resilience, self-esteem, severity of dependence and readiness to change before and after spiritual counselling. Along with the interview schedule prepared by the researcher, the following tools were used: Patient Health Questionnaire 9, Rosenberg Self Esteem Scale, Brief Resilience Scale, Severity of Dependence and Readiness to Change Scale. Data was collected by the researcher before and after intervention. The analysis of data showed that there was a significant change in the level of depression, coping, resilience, self-esteem and readiness to change among the alcoholics due to spiritual counselling. It is suggested that spiritual counseling can be included as a model of de-addiction treatment along with other modes of intervention. It also can be included in Social Work curriculum especially in mental health field.

\section{KEYWORDS : Alcohol Addiction, Spiritual Counselling, Coping, Resilience, Self-Esteem}

\section{INTRODUCTION}

Drug abuse or chemical dependence is a deadly virus that spreads in Universities and Schools like an epidemic outburst (Matthews, 2004). Today drug culture is wide and extensive (Adekeye, Olujide A, 2015). The motivating factors for initiating drug such as: search for pleasure and variety of pain probably remain the same in many cases, but other factors such a curiosity, boredom peer pressure, unemployment and frustration also plays a major role(Chunkapura, 1994)(Aneshensel, 1983).Spiritual Counseling is one mode of intervention practiced in many de-addiction centers. But their effectiveness were not often studied scientifically and ignored by the de addiction professionals. This study aims at finding out the effectiveness of spiritual counseling as a mode of intervention among the alcohol addicts with respect to the NGO TRADA in Kottayam, Kerala.

\section{Objectives of the research}

\section{General Objective}

To study the effectiveness of Spiritual Counseling as a mode of intervention on persons addicted to Alcohol

\section{Specific Objectives}

- To study the socio-economic background of the respondents

- To study the factors leading to alcohol addiction and the patterns of drinking.

- To study the attitude of the persons addicted to alcohol towards life and mental health before and after attending Spiritual Counseling.

- To study the coping strategies and resilience level of the persons addicted towards alcohol before and after attending Spiritual Counseling.

- To study the self-esteem level of the persons addicted towards alcohol before and after attending Spiritual Counselin

- To study the attitude of the respondents towards de-addiction treatment with a special note to spiritual counseling

\section{Research Hypotheses}

The following were the research hypotheses used in the study:

1. There is no significant reduction in the level of depression among the respondents due to spiritual counselling

2. There is no significant improvement in the level of coping among the respondents due to spiritual counselling

3. There is no significant improvement in the level of resilience among the respondents due to spiritual counselling

4. There is no significant improvement in the level of self- esteem among the respondents due to spiritual counselling
5. There is no significant relationship between readiness to change among the respondents and spiritual counselling

\section{Field of Study}

The field of study for the research is TRADA, Kottayam.

The All Kerala Joint Christian Temperance Movement (Started in 1961 by all the Christian Bishops of Kerala) was in the forefront of the crusade against Alcoholism and Drug addiction through its various diocesan and parish level units in almost all Christian churches in Kerala. The Total Response to Alcohol and Drug Abuse (TRADA) was started on September 7, 1987 for the treatment of Addiction and for awareness creation among the public about addiction(Joan Chunkapura,Chackochan Kalappura, 1987).

\section{TRADA Model of Treatment}

The de-addiction treatment in TRADA is for three months. The first week of the treatment focuses on medical treatment which is on detoxification. Then the remaining days, till the end of first month, one on one spiritual counselling, Alcoholic Anonymous, spiritual retreat,group therapy and family therapy are used in this model of treatment. Professionally trained social workers, psychologists, psychiatrists and nurses are part of the TRADA team.

\section{Research Design}

The Research Design used is Quasi - Experimental Research Design with Before and After without Control group.

\section{Universe}

The Universe of the study were the persons treated at TRADA in the months of May andJune, 2017 which include a sample size of 20 respondents. TRADA takes only 20 respondents for each session.

\section{Sampling Technique}

The census method of data collection was followed. All the respondents in the universe were taken for sampling $(\mathrm{n}=20)$.

\section{Characteristics of Sampling}

- All male respondents

- Addicted to alcohol for 5 years or more

- Attending spiritual counseling in TRADA

\section{Tools of Data Collection}

A Structured Interview Schedule along with the following scales were used as tools of data collection.

\begin{tabular}{|l|l|l|l|l|c|}
\hline Sl.No & Scale of assessment & Source & $\begin{array}{l}\text { Number } \\
\text { of items }\end{array}$ & Type of Scale & Reliability \\
\hline 1. & Patient Health Questionnaire 9 & $\begin{array}{l}\text { Robert L. Spitzer and Colleagues } \\
2011\end{array}$ & 9 & $\begin{array}{l}\text { Likert type scale (0-Not at all - 3- } \\
\text { Nearly every day) }\end{array}$ & 0.85 \\
\hline
\end{tabular}


Volume-10 | Issue-2 | February - 2020 | PRINT ISSN No. 2249 - 555X | DOI : 10.36106/ijar

\begin{tabular}{|c|c|c|c|c|c|}
\hline 2. & Rosenberg Self Esteem Scale & \begin{tabular}{|l} 
M. Rosenberg, \\
1965 \\
\end{tabular} & 10 & $\begin{array}{l}4 \text { point Likert Scale } \quad \text { (1-Strongly } \\
\text { Disagree }-\quad \text { 4-Strongly agree) }\end{array}$ & 0.90 \\
\hline 3. & Brief Resilience Scale & $\begin{array}{l}\text { Smith and Colleagues, } \\
2008\end{array}$ & 6 & $\begin{array}{l}5 \text { point Likert Scale } \quad \text { (1-Strongly } \\
\text { Disagree }-\quad 5 \text {-Strongly agree) }\end{array}$ & 0.83 \\
\hline 4. & $\begin{array}{l}\text { Severity of Dependence and } \\
\text { Readiness to Change Scale }\end{array}$ & $\begin{array}{l}\text { Alcohol and Drug Training and Research } \\
\text { Unit, University of Queensland, } 2002\end{array}$ & 7 & $\begin{array}{l}\text { Likert type scale (0-Never or } \\
\text { almost never-3-Always) }\end{array}$ & 0.70 \\
\hline
\end{tabular}

\section{Findings}

Majority of the respondents were from the age group of 30-40 years, married and were employed. Respondents' father's substance abuse was a major factor that leads to alcoholism. Peer influence was also an influencing factor for addiction. The time of initial use of alcohol for almost half of the respondents was between 15 years to 20 years (Ramanathan, 2012)(Poikolainen, 2000)(Bond, 2017).

The researcher used Paired sample T-Test for testing hypotheses and found that there was a reduced level of depression among the respondents after spiritual counselling, the level of coping, resilience, self-esteem and readiness to change have increased after spiritual counselling(Mary W. Kuria, David M. Ndetei, Isodore S. Obot, Lincoln I. Khasakhala, Betty M. Bagaka, Margaret N. Mbugua,and Judy Kamau, 2012)(Krok, 2008)(Burke, 2008). Financial problems and health problems of the respondents still continued after spiritual counselling (Marytriza Muraguri, 2014).There was a significant correlation between the level of self-esteem and the severity of dependence among the respondents. It was because of the lower selfesteem that many of the respondents were addicted towards alcohol as a way of displacement(Drug and Rehab, Thailand, 2018).

\section{DISCUSSION}

The research findings show the importance of spiritual counseling as a mode of intervention on persons addicted to alcohol. It's evident that the spiritual counseling has caused not only the level of depression to come down but also have improved the level of coping, resilience, selfesteem and severity of dependence. Thus the study suggests that professional social work must also recognize the spiritual aspect of a person. Thus spiritual therapies can also be a part of social work and even specializations can be formed out of it (Miriam, 2016).

\section{Recommendation}

The following were the recommendations made by the researcher based on the findings of the study:

\section{Holistic Model of de-addiction}

Though there were significant impact due to spiritual counselling, it should be noted that financial and health problems still prevailed among the respondents even after spiritual counselling. Thus a holistic model of de-addiction treatment can be practiced in de-addiction centers. The holistic wellness model introduced by Jung (1954) recommends that the therapist introduce spiritual ideas and experiences for the client's personal development and wellness along with physical, emotional, social, occupational and intellectual components of therapy.

\section{To the Church}

Since this research has given prime importance on the spiritual intervention to the problem of alcoholism, the church and Christianity has got to play a major role on this issue. It was evident from the research that the amount of consumption of alcohol among Christians were much higher when compared to other religions in this present study population. It was also supported by the review that consumption of alcohol is not considered as a sin in some religions especially among the Catholics and Knanaya(Blackburn, 2008).

\section{To the Government}

The research data revealed that five percent of the respondents who consumed alcohol were below twenty. The minimum age for purchase and consumption of alcohol was 21 years when the researcher carried out the research, then it was then raised to 23 years in December, 2017 by the Kerala state government. Thus the government machinery can implement aadhar card as an age proof to procure alcohol.

\section{To the NGOs}

The problems related to alcoholism cannot be dealt by the government alone. The NGOs and churches thus have to come forward to address this issue. More number of NGOs can be trained towards de-addiction treatment with the help of professionals. There has been a steep rise on the number of alcohol addicts and a combined and coordinated efforts are needed.

\section{To the Social Work Curriculum}

The spiritual counselling has to be given by persons who are well trained in the respective field. Thus it is strongly suggested to include spiritual counselling in social work curriculum.

\section{CONCLUSION}

There is effectiveness in spiritual counseling among the persons addicted to alcohol with respect to their level of depression, attitude towards life and mental health, coping, resilience and readiness to change. Thus this model of treatment can be implemented in various de-addiction centers with reference to the 'Holistic Wellness Model' in accordance with the above mentioned suggestions. Spiritual Wellness is an integral dimension of holistic development. Spiritual wellness is not an indefinable, unworkable concept. It is a part of the human being that needs to be attended to and fostered as much as to the mind and body. Social Workers working as de-addiction counselors, by virtue of their professional description as promoters of human development, are likely facilitators for the enhancement of spiritual wellness.

\section{REFERENCES}

1. Adekeye, Olujide A. (2015). Assessment of Alcohol and Substance Use among Undergraduates in Private Universities. IOSR Journal Of Humanities And Social Science

2. Aneshensel, C. \&. (1983). Depression, alcohol use, and smoking over one year: A four way longitudinal Model. Journal of Abnormal Behaviour, 134-150.

3. Blackburn, J. (2008, February 2). https://www.catholic.com/ magazine/printedition/got-wine. Retrieved from https://www. catholic.com.

4. Bond, J. L. (2017). Factors That Influence Teenagers to Substance Abuse

5. Burke, P. A. (2008). Enhancing Hope and Resilience Through a Spiritually Sensitive Burke, P. A. (2008). Enhancing Hope and Resilience Through a Spiritually Sensitive
Focus in the Treatment of Trauma and Addiction. Journal of Chemical Dependency Focus in the Treatm
Traetment, $187-206$.

6. Chunkapura, J. (1994). Treatment Models In Addiction. Kottayam: TRADA Publications.

7. Drug and Rehab, Thailand. (2018).

8. Joan Chunkapura,Chackochan Kalappura. (1987). Lahari Chikilsa. TRADA Publications.

9. Krok, D. (2008). The role of spirituality in coping: Examining the relationships between spiritual dimensions and coping styles. Mental Health, Religion and Culture.

10. Mary W. Kuria, David M. Ndetei, Isodore S. Obot, Lincoln I. Khasakhala, Betty M. Bagaka, Margaret N. Mbugua,and Judy Kamau. (2012). The Association between Bagaka, Margaret N. Mbugua,and Judy Kamau. (2012). The Association between
Alcohol Dependence and Depression before and after Treatment for Alcohol Alcohol Dependence and Depression before and after
Dependence. International Scholarly Research Notices, 6.

11. Marytriza Muraguri, M. N. (2014). Mental Health Effects and Assessment Tools of Alcoholism among the Elderely. Central University of Applied Sciences.

12. Matthews. (2004). Alcohol use amongst tertiary students.

13. Miriam, K. (2016). Gender differences in impact of perceived stress on mental health Examining the role of resilience and social support as mediators and moderators. Chennai.

14. Poikolainen, K. (2000). Risk Factors For Alcohol Dependence: A Case-Control Study. Alcohol and Alcoholism.

15. Ramanathan, D. N. (2012). Family-The Prime Influencer of Alcoholism among People of Kerala. International Journal of Multidisciplinary Management Studies . 